\title{
PELAYANAN NASABAH BRI CABANG BUNTOK MENGGUNAKAN APLIKASI MOBILE BANKING PADA TAHUN 2017
}

\section{Customer Service of BRI Branch Buntok using Mobile Banking Applications in 2017}

\author{
*Harlina Kuriaty \\ Management Study Program, Institute of Economic Science Dahani Dahanai, Buntok, Indonesia
}

\begin{abstract}
ABSTRAK
Aplikasi mobile banking BRI adalah salah satu jenis pelayanan yang tidak langsung oleh BRI kepada nasabahnya, dimana pelayanannya hanya menggunakan aplikasi yang melekat pada handphone nasabah. Penelitian mengenai aplikasi mobile banking BRI ini bertujuan untuk mempelajari dan memahami cara penggunaan fasilitas aplikasi mobile banking BRI dan menganalisis faktor - faktor yang mempengaruhi efektivitas dan efisiensi fasilitas mobile banking BRI. Adapun faktor kualitas pelayanan yang digunakan untuk melihat efektivitas dan efisiensi dalam penggunaan aplikasi mobile banking BRI meliputi Tangibles / bukti langsung, Reliability / Keandalan, Responsiveness / ketanggapan, Assurance / Jaminan dan Emphaty / empati. Nasabah yang diteliti adalah sebanyak 10 nasabah BRI Cabang Buntok pengguna aktif mobile banking BRI. Metode penelitian menggunakan metode Triangulasi , Hasil dari wawancara langsung dengan 3 nasabah pengguna aktif mobile banking BRI yang berprofesi sebagai Pegawai Negeri Sipil, Pegawai Swasta, dan Mahasiswa, berdasarkan 5 kualitas pelayanan mengatakan bahwa menggunakan mobile banking BRI ternyata lebih efektif dan efisien daripada datang langsung ke Bank, serta dilihat dari empat faktor penghambat pelayanan dapat disimpulkan bahwa pelayanan menggunakan aplikasi mobile banking mempunyai faktor penghambat dalam pelayanannya yaitu jaringan yang sering susah dan gangguan sistem.
\end{abstract}

Kata kunci: Pelayanan, Aplikasi Mobile Banking, BRI

\begin{abstract}
$B R I$ mobile banking application is one of the indirect services by BRI to its customers, where the service only uses the application attached to the customer's mobile phone. The research on BRI's mobile banking application is aimed to learn and understand how to use BRI's mobile banking application facilities and analyze the factors that affect the effectiveness and efficiency of BRI's mobile banking facilities. The service quality factors used to see the effectiveness and efficiency in the use of BRI mobile banking applications include Tangibles / direct evidence, Reliability / Reliability, Responsiveness / Assumptions, Assurance / Assurance and Emphaty / empathy. The customers studied are as many as 10 BRI customers of Buntok branch of active BRI mobile banking users. The method of this research is Triangulation method. The result of direct interview with 3 active customers of BRI mobile banking who work as Civil Servant, Private Officer, and Student, based on 5 service quality said that using BRI mobile banking is more effective and efficient than coming directly to Bank, and seen from four inhibiting factors of service can be concluded that service using mobile banking application have inhibiting factor in its service that is often difficult network and system interference.
\end{abstract}

Keywords: Service, Mobile Banking Application, BRI

\section{PENDAHULUAN}

Perkembangan teknologi berkembang secara drastis dan terus berevolusi hingga sekarang dan semakin mendunia. Hal ini dapat dibuktikan dengan banyaknya inovasi dan penemuan yang sederhana hingga sangat rumit. Bahkan kurang dari 10 tahun terakhir, teknologi handphone yang awalnya hanya sebuah komunikasi nirkabel berkembang menjadi alat komunikasi yang dapat mengambil foto, merekam video, mendengarkan musik, dan mengakses internet dalam hitungan detik. Tidak heran jika berbagai perusahaan perusahaan ternama di Indonesia berlomba lomba untuk meningkatkan kualitas barang dan jasanya dengan cara memanfaatkan perkembangan teknologi. Salah satunya adalah 
PT. Bank Rakyat Indonesia (Persero) Tbk. Pemanfaatan teknologi informasi ini menjadi suatu kebutuhan untuk mendukung perkembangan bisnis di sektor perbankan. Pemanfaatan teknologi secara tepat juga harus diperhatikan, untuk meminimalkan kelancaran dan kemudahan kegiatan perbankan. PT Bank Rakyat Indonesia (Persero) Tbk adalah salah satu Bank milik pemerintah yang terbesar di Indonesia dan merupakan perbankan yang sangat menjunjung tinggi kepuasan nasabah, oleh karena itu BRI selalu berusaha meningkatkan kualitas dan pelayanannya. Salah satunya adalah dengan selalu mencari inovasi terbaru untuk menarik minat dan perhatian nasabah serta memberi kemudahan untuk nasabahnya, karena kepuasan nasabah merupakan kunci utama dan menjadi tolak ukur kemajuan bisnis BRI kedepannya.

Mobile Banking adalah salah satu fasilitas BRI yang bisa dibawa kemana saja dan kapan saja, karena fasilitas ini berbentuk aplikasi yang selalu melekat di handphone penggunanya. Seperti yang kita ketahui bersama bahwa pada dasarnya handphone adalah suatu alat komunikasi yang harus selalu kita bawa dan bahkan tanpa kita sadari handphone akan selalu kita bawa kemanapun kita pergi.Dengan adanya aplikasi Mobile Banking dihandphone kita maka kita bisa bertransaksi dimanapun kita berada, contohnya seperti transaksi transfer, info saldo, isi ulang pulsa, melakukan pembayaran seperti pembayaran PLN, Telkom, Kartu Kredit, BRIVA bahkan tiket pesawat pun bisa dibayar hanya melalui handphone. Mobile Banking adalah fasilitas perbankan melalui komunikasi bergerak seperti handphone menggunakan media SMS dengan nomor tujuan 3300 untuk semua jenis handphone dan semua operator telekomunikasi. Dengan penyediaan fasilitas yang hampir sama dengan ATM kecuali mengambil uang cash. Mobile Banking pada umumnya disebut M-Banking yang merupakan sebuah sistem layanan dari sebuah lembaga keuangan seperti Bank untuk melakukan sejumlah transaksi keuangan yang dapat diakses langsung oleh nasabah melalui perangkat mobile seperti telepon seluler.

\section{METODOLOGI}

Jenis penelitian ini merupakan penelitian kualitatif. Yang menjadi fokus penelitian penulis pada penelitian ini adalah pelayanan terhadap nasabah BRI hanya pada pelayanan aplikasi Mobile Bankingnya saja.Mobile Banking BRI adalah bentuk pelayanan BRI secara tidak langsung, tanpa tatap muka dengan petugas bank dan hanya memberikan pelayanan melalui sebuah aplikasi yang dirancang sedemikian rupa untuk membantu nasabah dalam bertransaksi.

\section{HASIL DAN PEMBAHASAN}

Ada beberapa keunggulan dari penggunaan Mobile Banking BRI adalah sebagai berikut:

1. Mudah, khusus untuk Mobile Banking berbasis menu transaksi dapat dilakukan dengan langsung memilih menu / fitur transaksi yang diinginkan tanpa perlu mengingat format SMS.

2. Aman, dilengkapi dengan PIN sebagai otorisasi transaksi.

3. Cepat, dengan berbasis pada SMS, transaksi dapat langsung dilakukan tanpa didahului dengan proses login diaplikasi.

Adapun kelebihan dan kelemahan Mobile Banking adalah sebagai berikut: 


\section{Kelebihan Mobile Banking}

a. Layanan mobile banking yang ditawarkan oleh hampir semua Bank adalah bebas biaya. Ini berarti bahwa pelanggan dapat menangani kerumitan bebas transaksi tanpa biaya tambahan.

b. Ada tiga cara dimana layanan ini dapat diakses dari mobile tergantung pada kompatibilitas ponsel.Hal ini membuat mobile banking tersedia untuk semua orang.Yang pertama adalah melalui SMS dimana informasi saldo dan password perbankan akan dikirim ke pengguna melalui SMS.Kedua, beberapa Bank telah mendedikasikan aplikasi perangkat lunak yang dapat didownload diponsel untuk mengakses rekening Bank.Ketiga, ponsel yang memiliki fasilitas internet browser dapat mengakses aplikasi perbankan dengan mudah seperti komputer.

c. Server Bank dienkripsi untuk transaksi nirkabel. Ini berarti bahwa mode ini transaksi sebenarnya bisa lebih baik dijamin dari transaksi melalui koneksi kabel.

d. Informasi rekening bersama dengan nomor rekening tidak ditampilkan pada koneksi nirkabel. Hal ini membantu lebih terhadap keamanan data.

e. Menghemat waktu.

f. Lebih fleksibel.

g. Mudah digunakan.

2. Kekurangan Mobile Banking

a. Risiko keamanan terbesar dalam mobile banking adalah non - dienkripsi server penyedia layanan ponsel. Hal ini relatif sangat mudah bagi seorang hacker ahli untuk mendapatkan informasi account atau debit dan informasi kartu kredit dari pengguna.

b. Pesan yang diterima dari Bank tidak dienkripsi. Artinya, informasi yang bisa dengan mudah dicari saat sedang dikirim melalui operator selular.

c. Jika ponsel hilang atau dicuri, informasi yang tersimpan dalam pesan dapat digunakan dengan mudah oleh orang lain.

d. Ponsel yang menggunakan browser internet tetapi tidak memiliki antivirus berada pada risiko yang sangat tinggi untuk informasi sensitif.

e. Tidak bisa melakukan penarikan tunai.

f. Bergantung pada pulsa dan jaringan.

Dalam penelitian ini peneliti melakukan wawancara langsung kepada tiga nasabah yang berprofesi sebagai Pegawai Negeri Sipil (PNS), Pegawai Swasta dan Mahasiswa dan bersedia memberikan informasi mengenai pengalamannya selama menggunakan aplikasi mobile banking BRI.Semua nasabah dalam Nara sumber penelitian ini tidak merasa keberatan untuk disebutkan namanya, adapun nasabah penelitian ini adalah sebagai berikut:

1. Ibu Isnah CholisohM.Pd. (Pengawas di Dinas Pendidikan Kabupaten Barito Selatan sekaligus pemilik dan Ketua Yayasan Bina Insan Nusantara Barito), Ibu Isnah Cholisoh, M.Pd. merupakan nasabah ketiga yang sangat terbuka dalam menceritakan pengalamannya dalam hal penggunaan mobile banking BRI.

2. Bapak Ahmad Bahesti (Administrasi Manager di PT. Meratus Borneo Sakti Buntok), Bapak Ahmad Bahesti merupakan nasabah keempat dalam penelitian ini, dan Beliau memberikan informasi sesuai dengan apa adanya. 
3. Ibu Nabella Permadya Santi (Ibu Rumah Tangga sekaligus Mahasiswa Universitas Terbuka Buntok), Ibu Nabella Permadya Santi merupakan nasabah ketujuh yang menyambut dengan ramah pertanyaan demi pertanyaan dari peneliti.

Tangibles merupakan bukti nyata dari kepedulian dan perhatian yang diberikan oleh penyedia jasa kepada konsumen. Pentingnya dimensi tangibles ini akan menumbuhkan image penyedia jasa terutama bagi konsumen baru dalam mengevaluasi kualitas jasa. Perusahaan yang tidak memperhatikan fasilitas fisiknya akan menumbuhkan kebingungan atau bahkan merusak image perusahaan.

Untuk mengetahui apakah bukti langsung yang dirasakan oleh nasabah dalam pelayanan mobile banking BRI, maka peneliti menanyakan pertanyaan berikut kepada nasabah:

"Apa bukti langsung yang dirasakan selama menggunakan mobile banking BRI?"

Berdasarkan hasil wawancara dengan nasabah pertama yaitu Ibu Isnah Cholisoh, M.Pd., Beliau pun menjawab sebagai berikut bahwa:

"Yang saya rasakan selama menggunakan mobile banking BRI adalah banyak kemudahannya terutama pada saat transaksi pembelian barang barang online, disitu saya merasakan dari segi waktu yang efisien, sehingga saya tidak perlu pergi ke ATM. Karena hanya dengan mengirimkan SMS, saya sudah bisa transfer uang untuk membeli barang yang saya inginkan".

Kemudian peneliti juga menanyakan hal yang sama kepada nasabah kedua yaitu Bapak Bahesti, dan Beliau pun menjawab bahwa:

"Bukti langsung yang saya rasakan tentunya lebih mudah, karena saya tidak perlu keluar rumah untuk cek saldo dan transfer. Semuanya cukup hanya menggunakan handphone".

Dan peneliti juga menanyakan hal yang sama lagi kepada nasabah ketiga yaitu Ibu Nabella Permadya Santi, seorang mahasiswa Universitas Terbuka Cabang Palangkaraya, Beliau pun menjawab bahwa:

"Menggunakan mobile banking BRI itu lebih mudah, tidak perlu jalan keluar, lebih enak. Namun jika transaksinya besar, saya lebih memilih pergi ke ATM".

Dari hasil wawancara tersebut di atas dapat disimpulkan bahwa bukti langsung yang dapat dirasakan nasabah sebagai bentuk kepedulian dan perhatian yang diberikan oleh aplikasi mobile banking BRI adalah lebih memudahkan nasabah dalam bertransaksi seperti belanja online, cek saldo dan transfer serta tidak perlu keluar rumah untuk bertransaksi tersebut.

Reliability atau keandalan merupakan kemampuan perusahaan untuk melaksanakan jasa sesuai dengan apa yang telah dijanjikan secara tepat waktu. Pentingnya dimensi ini adalah kepuasan konsumen akan menurun bila jasa yang diberikan tidak sesuai dengan yang dijanjikan. Jadi komponen atau unsur dimensi reliability ini merupakan kemampuan perusahaan dalam menyampaikan jasa secara tepat dan pembebanan biaya secara tepat.

Wawancara dilakukan dengan nasabah yang sama bahwa keandalan yang dirasakan nasabah yang merupakan kemampuan perusahaan untuk melaksanakan jasa secara tepat waktu. Peneliti menanyakan kepada nasabah sebagai berikut: "Bagaimana pelayanan mobile banking BRI dilihat dari segi waktu pelayanannya?" Ibu Isnah Cholisoh, M.Pd. pun menjawab bahwa: 
"Menggunakan mobile banking BRI adalah lebih efisien waktu karena kita tidak perlu ke teller lagi untuk bertransaksi, cukup secara otomatis menggunakan handphone kita saja dalam pembayaran seperti pembayaran pulsa dan listrik" Kemudian peneliti melanjutkan pertanyaan yang sama kepada Bapak Bahesti dan Beliau pun juga menjawab bahwa:

"Kalau dilihat dari segi waktunya, pelayanan mobile banking lebih cepat daripada harus datang langsung ke Bank, karena kalau datang langsung ke Bank kan kita harus membuang waktu, belum lagi kalau antri di ATM". Ibu Nabella Permadya Santi juga menjawab pertanyaan peneliti bahwa: "Dalam penggunaannya sangat simple, tidak perlu ke Bank dan pada saat ada keperluan yang cepat kita bisa bertransaksi seperti mengirim uang untuk kepentingan anak, transfer untuk kepentingan bisnis, pembelian token dan semua menu yang ada dalam mobile banking tersebut. Jika dibandingkan dengan harus datang langsung ke Bank untuk bertransaksi, saya lebih mudah menggunakan mobile banking karena manfaatnya sangat banyak, sehingga tidak perlu membuang waktu untuk datang ke Bank, apalagi kalau antri. "Dari hasil wawancara tersebut di atas dapat disimpulkan bahwa konsumen atau nasabah BRI yang menggunakan aplikasi mobile banking merasakan tingkat kepuasan terhadap transaksi yang dilakukan dengan menggunakan mobile banking merupakan kemampuan perusahaan dalam menyampaikan jasa secara tepat dan pembebanan biaya secara tepat seperti tidak harus membuang waktu keluar rumah untuk melakukan transaksi dan tidak perlu antri ke Bank sehingga kita bisa melakukan transaksi dengan cepat.
Responsiveness atau daya tangkap merupakan kemampuan perusahaan yang dilakukan oleh langsung karyawan untuk memberikan pelayanan dengan cepat dan tanggap. Daya tanggap dapat menumbuhkan persepsi yang positif terhadap kualitas jasa yang diberikan. Termasuk didalamnya jika terjadi kegagalan atau keterlambatan dalam penyampaian jasa, pihak penyedia jasa berusaha memperbaiki atau meminimalkan kerugian konsumen dengan segera. Dimensi ini menekankan pada perhatian dan kecepatan karyawan yang terlibat untuk menanggapi permintaan, pertanyaan, dan keluhan konsumen. Jadi komponen atau unsur dari dimensi ini terdiri dari kesigapan karyawan dalam melayani pelanggan, kecepatan karyawan dalam melayani pelanggan dan penanganan keluhan pelanggan.

Dari hasil wawancara terhadap nasabah yang menggunakan mobile banking BRI bahwa merupakan ketanggapan yang dirasakan nasabah adalah pelayanan yang cepat dan tanggap. Peneliti pun memberikan pertanyaan ketiga kepada nasabah yang sama sebagai berikut:

"Apakah selama ini mobile banking memberikan pelayanan yang cepat dan tanggap?".

Ibu Isnah Cholisoh, M.Pd. menjawab bahwa:

"Selama ini pelayanan mobile banking cukup cepat dan tanggap dalam pelayanannya, dimana pada saat kita ingin cek saldo maka kita segera mendapatkan informasi tersebut dengan cepat".

Kemudian Bapak Bahesti juga menjawab pertanyaan yang sama bahwa: "Manfaat dari penggunaan mobile banking BRI sangat banyak, seperti cek saldo, beli pulsa, transfer dan pembayaran apapun bisa dimana saja dan kapan saja. Selain itu sangat mempermudah dan sangat mendukung pekerjaan yang serba online, transaksi 
non tunai pun sering digunakan sehingga sangat terbantu dengan adanya aplikasi mobile banking karena saya tidak perlu antri dan waktunya lebih cepat".

Setelah mendapat jawaban dari nasabah kedua, peneliti pun beralih ke nasabah ketiga dengan pertanyaan yang sama dan Ibu Nabella Permadya Santi pun juga menjawab bahwa:

"Pelayanan mobile banking sangat cepat dan lebih mudah, sehingga saya tidak perlu repot - repot lagi harus kesana kemari, kan saying sama bensin". Dari hasil wawancara tersebut di atas dapat disimpulkan bahwa responsiveness atau daya tangkap yang dilakukan oleh Aplikasi Mobile Banking untuk memberikan pelayanan dengan cepat dan tanggap, yang memiliki persepsi yang positif terhadap kualitas jasa yang diberikan. Dimensi ini menekankan pada perhatian dan kecepatan pelayanan aplikasi dalam melakukan transaksi. Jadi komponen atau unsur dari dimensi responsiveness ini terdiri dari kesigapan pelayanan mobile banking dalam melayani nasabah, kecepatan mobile banking dalam melayani nasabah dan penanganan keluhan nasabah apabila ada terjadi kendala dan permasalahan dalam menggunakan aplikasi mobile banking BRI.Menggunakan aplikasi mobile banking lebih cepat daripada datang langsung ke Bank.

Assurance / jaminan merupakan pengetahuan dan perilaku employee untuk membangun kepercayaan dan keyakinan pada diri konsumen dalam mengkonsumsi jasa yang ditawarkan. Dimensi ini sangat penting karena melibatkan persepsi konsumen terhadap risiko ketidakpastian yang tinggi terhadap kemampuan penyedia jasa. Perusahaan membangun kepercayaan dan kesetiaan konsumen melalui karyawan yang terlibat langsung menangani konsumen. Jadi konsumen dari dimensi ini terdiri dari kompetensi karyawan yang meliputi keterampilan, pengetahuan yang dimiliki karyawan untuk melakukan pelayanan dan kredibilitas perusahaan yang meliputi hal - hal yang berhubungan dengan kepercayaan konsumen kepada perusahaan seperti reputasi perusahaan, prestasi dan lain lain.

Untuk melihat unsur jaminan dalam pelayanan kepada nasabah maka peneliti makukan wawancara terhadap nasabah BRI yang menggunakan mobile banking BRI bahwa jaminan yang dirasakan oleh nasabah merupakan kepercayaan, kesetiaan dan keyakinan pada mobile banking BRI. Untuk mengetahui kualitas Assurance / jaminan dalam pelayanan mobile banking BRI, maka peneliti memberikan pertanyaan sebagai berikut kepada ketiga nasabah:

"Apa jaminan yang Bapak / lbu rasakan selama menggunakan mobile banking BRI?".Ibu Isnah Cholisoh, M.Pd. langsung menjawab bahwa: "Saya senang menggunakan mobile banking karena mudah penggunaannya, praktis, tidak perlu ke ATM atau datang langsung ke kantornya, hanya di rumah apa saja bisa bertransaksi seperti pembelian.Intinya nyaman dan saya lebih memilih menggunakan mobile banking ."Bapak Bahesti juga menjawab bahwa: "Saya merasa kalau menggunakan mobile banking saya merasa aman, karena pada saat bertransaksi saya selalu dilindungi oleh password dan jika kita mau transfer, kita selalu diyakinkan dengan datangnya konfirmasi lagi dari mobile bankingnya apakah kita sudah benar memasukkan nomor rekening tujuan 
dan penerimanya atau belum ". Setelah itu, Ibu Nabella Permadya Santi pun menjawab bahwa: "Sejauh ini saya sih masih percaya dengan mobile banking BRI, karena kemudahan dan kenyamanan yang selalu diberikan. Pada saat transaksi kita belum berhasil terkirim, kita selalu dapat informasi bahwa transaksi yang kita kirim gagal, jadi kita tidak pernah takut kalau uang kita hilang“. Dari hasil wawancara tersebut di atas dapat disimpulkan bahwa jaminan dari mobile banking BRI adalah segala transaksi yang dilakukan melalui mobile banking BRI merupakan jaminan bahwa transaksi tersebut adalah merupakan bukti sah yang dapat dirasakan langsung oleh nasabah. Dan besarnya dana dalam melakukan transaksi bisnis melalui mobile banking BRI langsung masuk ke rekening antar penjual dan pembeli. Pemberitahuan yang disampaikan melalui sms ke HP pengguna aplikasi mobile banking merupakan jaminan dari sebuah transaksi keuangan. Selain itu password juga merupakan jaminan keamanan dalam bertransaksi.

Emphaty merupakan kemampuan perusahaan yang dilakukan langsung oleh karyawan untuk memberikan perhatian kepada konsumen secara individu, termasuk juga kepekaan akan kebutuhan konsumen. Jadi komponen juga dari dimensi ini merupakan gabungan dari akses (access) yaitu kemudahan untuk memanfaatkan jasa yang ditawarkan oleh perusahaan, komunikasi merupakan kemampuan melakukan untuk menyampaikan informasi kepada konsumen atau memperoleh masukan dari konsumen dan pemahaman merupakan usaha untuk mengetahui dan memahami kebutuhan dan keinginan konsumen.
Dalam hal ini perhatian perusahaan kepada nasabah BRI juga dilakukan termasuk kepekaan kebutuhan nasabah pada waktu - waktu tertentu, misalnya ketika nasabah memerlukan informasi saldo rekening pribadi, bisa di informasikan melalui sms. Dan lebih mudah lagi apabila nasabah menggunakan aplikasi mobile banking BRI. Untuk melihat kualitas empati mobile banking terhadap nasabah, maka peneliti memberikan pertanyaan berikut kepada nasabah:

"Apa wujud empati dari pelayanan mobile banking BRI selama ini?".

Dari hasil wawancara tersebut di atas bahwa bentuk empati yang diberikan dalam pelayanan mobile banking BRI adalah memahami dan memenuhi kebutuhan nasabah bertransaksi apa saja yang diinginkannya.

\section{KESIMPULAN}

Aplikasi mobile banking $\mathrm{BRI}$ adalah salah satu jenis pelayanan yang tidak langsung oleh BRI kepada nasabahnya, dimana pelayanannya hanya menggunakan aplikasi yang melekat pada handphone nasabah.

Aplikasi mobile banking memiliki kelebihan sebagai berikut:

1. Layanan mobile banking yang ditawarkan oleh hampir semua Bank adalah bebas biaya. Ini berarti bahwa pelanggan dapat menangani kerumitan bebas transaksi tanpa biaya tambahan.

2. Ada tiga cara dimana layanan ini dapat diakses dari mobile tergantung pada kompatibilitas ponsel. Hal ini membuat mobile banking tersedia untuk semua orang. Yang pertama adalah melalui SMS dimana informasi saldo dan password perbankan akan dikirim ke 
pengguna melalui SMS. Kedua, beberapa Bank telah mendedikasikan aplikasi perangkat lunak yang dapat didownload diponsel untuk mengakses rekening Bank. Ketiga, ponsel yang memiliki fasilitas internet browser dapat mengakses aplikasi perbankan dengan mudah seperti komputer.

3. Server Bank dienkripsi untuk transaksi nirkabel. Ini berarti bahwa mode ini transaksi sebenarnya bisa lebih baik dijamin dari transaksi melalui koneksi kabel.

4. Informasi rekening bersama dengan nomor rekening tidak ditampilkan pada koneksi nirkabel. Hal ini membantu lebih terhadap keamanan data.

5. Menghemat waktu.

6. Lebih fleksibel.

7. Mudah digunakan.

Adapun kekurangan Mobile Banking adalah sebagai berikut:

1. Risiko keamanan terbesar dalam mobile banking adalah non - dienkripsi server penyedia layanan ponsel. Hal ini relatif sangat mudah bagi seorang hacker ahli untuk mendapatkan informasi account atau debit dan informasi kartu kredit dari pengguna.

2. Pesan yang diterima dari Bank tidak dienkripsi. Artinya, informasi yang bisa dengan mudah dicari saat sedang dikirim melalui operator selular.

3. Jika ponsel hilang atau dicuri, informasi yang tersimpan dalam pesan dapat digunakan dengan mudah oleh orang lain.

4. Ponsel yang menggunakan browser internet tetapi tidak memiliki antivirus berada pada risiko yang sangat tinggi untuk informasi sensitif.

5. Tidak bisa melakukan penarikan tunai.
6. Bergantung pada pulsa dan jaringan.

\section{DAFTAR PUSTAKA}

Abdullah, M. Faisal. 2005. Dasar - dasar Manajemen Keuangan, Edisi Kedua, Cetakan Kelima. Malang: Penerbitan Universitas Muhammadiyah.

Hardiyansyah. 2011.Kualitas Pelayanan Publik Konsep, Dimensi, Indikator dan Implementasinya. Yogyakarta: Gava Media.

Kasmir. 2000. Manajemen Perbankan. Jakarta :PT.Rajagrafindo Persada

Kasmir. 2003. Manajemen Perbankan. Jakarta: Radjagrafindo Persada

Kasmir.2008. Bank dan Lembaga Keuangan Lainnya. Edisi Revisi 2008. Jakarta: PT.Rajagrafindo Persada.

Kurniawan, Agung. 2005. Transformasi Pelayanan Publik. Yogyakarta: Pembaruan.

Moenir, H.A.S. 2010 . Manajemen Pelayanan Umum di Indonesia. Jakarta: Bumi Aksara.

Parasuraman,A., V. A.Zeithaml, dan L.L.Berry.1998. Servqual :A Multiple - Item Scale For Measuring Consumer Perceptions Of Service Quality, Journal Of Retailing, Vol.64,No.1.

Poerwadarminta.1985 .Kamus Umum Bahasa Indonesia. Jakarta: Balai Pustaka.

Ratminto \& Atik Septi Winarsih. 2013.Manajemen Pelayanan. Yogyakarta: Pustaka Belajar.

Sentra Pendidikan. 2017.Buku Saku E- Banking. Surabaya: Sentra Pendidikan BRI Corporate.

Zahnd, Markus. 2006. Perancangan Kota Secara Terpadu. Yogyakarta: Kanisius. 